\title{
The Spillover Effect of the EU Economy on the Culture
}

\section{Doina Gavrilov}

\author{
National School of Political and Administrative Studies, Bucharest, Romania \\ doina.gavrilov@yahoo.com
}

Keywords: Economy, Economic crisis, European Union, Culture

\begin{abstract}
The Economy has always been considered an essential pillar of development. This is why, when the European Union appeared, the idea of a community based on economic relations with the purpose of empowering the common economy seemed to be an attractive idea to the outside states of the European Economic Community. Even at first, the idea of empowering the Economy was a very good one, after politics, culture, agriculture, science, and other domains were directly linked to the economic development, the Economy was seen as the nucleus of development of all. Giving its role, we are asking ourselves: Is the Economy role only a positive one in the development of other domains? To understand the role that the fall of the Economy can have on other domains, we focus on economy-culture relation. Assuming the role of the effect of the Economic crises on the culture we conclude that the Economy should not be the only basis of development, but we should enlarge our possibilities of independence of other domains.
\end{abstract}

\section{Introduction}

The Economy role has been an important one for many years. In 1982 Heilbroner and Thurow sustain that all the World was due to the economy, even the international system is a result of the economy, because of economy links societies [1]. The authors give us the understanding that the Economy is not only the basis of the international system but also the seed of development of other domains like culture, politics and so on.

Starting from this point, we find it very interesting to understand if the Economy is the one to praise for the progress or also the one to blame for some regress.

A way to see the Economy impact on the domains is to look at how the Economy reacts on Economic crises. To see that, we see in the history of the European Union from 1973 until 2018, with a significant focus on the 2008-2009 financial crisis. To pursue this line of research, first of all, we underline a theoretical frame. We choose the neo-functionalist approach focusing on the spillover idea.

Why the neo-functionalism? Because it can help us see the domino effect of an economic crisis on the domains which development largely depend on the economy. We focus our research on a single area - culture. The neo-functionalist theory helps us analyze the domino effect that an economic crisis can have on culture by using the spillover idea.

We expect to see a significant impact of the economic crisis on the cultural field.

To see this, we will look at the 2008-2009 economic crisis impact on culture in a few European countries, and we will elucidate culture importance for the European Union.

\section{Terms Conceptualization}

The economy is a vital domain to the development of a state. One of its successful definitions was given in 2001 by Mankiw that finds the economy as a study of how society manages its resources [2]. In 2004 Krugman and Wells bring a similar definition to the economy, and underline that it "is a study at the individual level of all the economies and social development" [3]. The same idea had Clander in 2006. According to him "the economy is a study of human as an individual and the society as a whole with all its decisional mechanisms and traditions [4]. 
The economy is seen a little bit differently in 1803 by Jean- Baptiste Say that sees it as "a science that follows the productions process, the distributions, consumption and wealth [5].

Even the authors define the economy as a science, at a first look the word is defined differently in the dictionary. We have found a definition of the economy in the Financial Dictionary in 2018, which defines it as "a complex of measures and strategies adopted by the government to manage the economy, to achieve the objectives of economic nature. The measures taken by the government consist of Fiscal Policies, Monetary Policies, Prices, and Income Policies, Exchange rate. These measures suppose two kinds of activities: 1) Macro, in the field of employment security, price establishment, inflation, economic growth; 2) Micro, in the field of efficient use of the resources" [6].

In 2010, we found David Throsby's statement, according to which "we should focus on governmental activity in the cultural field, finances and wealth, industry and development, market, trade, education, and rural/urban development" [7].

We decide to use David Throsby definition of economy in our research supplied by Murgas and Bohm definition of the economy - "a central field of action, which contributes to the measurement of the national wealth and the good life" [8].

Even we have a definition to the Economy, we have a misunderstanding: What keeps making Economy the central field of action of a state? Looking back in the history we observe that the basis of the Economy is the economic policies. In the 1990s the economic policies were oriented on domestic product and public spendings. Starting with this moment, the economic policies "are focused on redistributive programs, right living, deficits of the government, monetary policy, business circle and so on" [9]. The economic policies "became a way of increasing the economic well being" [10].

We understand that the economic policies are an important aspect of the Economy, they are "the measures that the governments apply to influence the economy by allocative function or the stabilization and distributive function" [11].

The economic policies often have an impact on other domains. One of these domains is the cultural field, influenced by economic policies in the matter of business circle, employment subject and right living. From another point of view, culture is also crucial for the Economy. After World War II, in Europe culture represents the welfare of a state similar to the public services. Culture faced intelligence, democracy, and individualism harmonizing these with the cultural heritage" [13].

We can see that culture represents an important part of people's lives. Trying to define culture, we understand that it cannot be excluded from people's activities. In 1993 Biankini defines it as a domain which incorporates the visual and pre-electronic arts, cultural industry and the modernity [14]. In 2007 Dumont and Teller sustain the idea of culture being a part of day to day life of people saying that culture is a domain of policies interleaved with many other areas like popular culture, mass and day culture [15].

We observe that besides the national importance of culture, it starts to be a significant point of interest for the European Union. The European Parliament defines culture as "a sum of interactions between civilizations and national, regional, diverse local cultures" [13].

We can easily observe the different way of seeing culture in the eyes of the national states and the European Union. Giving this fact, we intend to shape a theoretical frame that will help us analyze the impact of the Economy on culture. In the next part of the paper, we will underline the neofunctionalist theory and the idea of spillover effect which will help us analyze the influence of the economic crisis on culture.

\section{The Theoretical Approach}

To analyze the Economy role in society, we choose the neo-functionalist theory through which we will see the basic ideas of our research.

Why the neo-functionalism? Because it can give us a broader look at the Economy role and also can provide us with evidence of the spillover effect role in the time of crisis.

In the 1950s the neo-functionalist theory is classified as the first theory of the European Integration. It concentrated on the economic changes in Europe after 1957. 
The neo-functionalist theory was a point of interest for many authors. In 2007, McGowan shaped the main ideas of the theory. Researching the subject in the EU, he finds that "the integration takes place when the organized economic interests put pressure on the government to manage the economic independence by centralizing policies and creating joint institutions also that the initial decision to integrate the above-described model produces the spillover effect that encourages the regional integration" [16].

In addition to McGowan observations comes I. G. Barbulescu, that brings a third idea of the theory which is related to the fact that "the organized economic interests are represented by the interest groups, political elites that sustain the European integration process" [17].

Eilsrup-Sangiovani also shared this idea in 2018. The author sees that the neo-functionalism has three main ideas: "1. The main actors in international relations are non-state actors. However, states are the final authorities in the integration process, able to oppose the integration. 2. Member States are united in their negotiating positions, which enables them to resist local and supranational interests. 3. The word spillover is critical in explaining neo-functionalism. Spillover is the automation of the integration process and encourages the integration in many other domains" [18].

Help to the "main idea of the neo-functionalist theory" [19], we will succeed in our research to analyze the role of Economy through the spillover effect by concentrating on splitting out the economic crisis consequences.

\section{Economy and Culture}

Since 1957, the European Community has focused on the four freedoms. The cultural field was not directly included in the talks but was an important part of the international relations. In 2015, Bodziany underlines a few reasons why culture was and still is an essential part of the international relations: a) the cultural objects and services were a part of the four freedoms, b) some states were afraid of cultural dominance, c) the national institutions were interested in keeping the national, regional, local cultures untouched by other cultures influence [20]. These arguments motivated the Community to take some steps in the matter of culture. As a result, in 1983, we have the Stugart Summit where was encouraged the cultural collaboration. In two years, the European states build the European Foundation entrusted with actions in the cultural field, communication, and exchange in education.

We have to underline that the first explicit emphasis of culture in the EU Treaties is in 1992, in the Maastricht Treaty, article 151. Since then, culture has been often mentioned in EU Treaties. In 1997 is signed the Amsterdam Treaty that contains the article 128 on culture. In 2007 is signed the Lisbon Treaty that includes article 6 on culture. We observe that the EU gives more and more attention to culture. We can note that by following the EU allocations for the cultural field. In 1983 the EU gave $1 \%$ of its budget for culture, then in 2002-2004 the EU offers between 32.2 and 34 million euros [13].

Since "culture and the arts are part of the cultural sector and together form socio-economic based on business and individuals who have dedicated their activity to producing and distributing cultural services" [21] it represents an essential sphere of the financial income which helps the economy to grow.

Starting from the idea that the EU is interested in culture as a part that sustains the economy to grow, Katharine Sarikakis sustain that the EU supports culture in the member states by funding and supporting the cultural preservation, the restoration of the cultural buildings, investing in non-media services and goods [22].

Looking at the EU actions, we see that it sustains the link between economy and culture also as a reason to access the national cultures. The EU has two ways of accessing culture and the cultural policies, see the table from below. 
Table 1: EU ways of accessing cultural policies.

\begin{tabular}{|c|c|}
\hline \multicolumn{2}{|c|}{ EU Ways of Accessing the Cultural Policies } \\
\hline $\begin{array}{l}\text { Direct (encourages projects and gives funds for } \\
\text { cultural development) }\end{array}$ & $\begin{array}{l}\text { Indirect (attaches cultural policies to the } \\
\text { economic and other policies) }\end{array}$ \\
\hline $\begin{array}{ll}\text { - } & \text { Europe for Citizens (2014-2020) } \\
\text { - } & \text { Creative Europe (2014-2020) } \\
\text { - } & \text { EURIMAGES (2014-2020) } \\
\text { - } & \text { HORIZON (2020) } \\
\text { - } & \text { CEB- Council of Europe Development } \\
& \text { Bank (2014-2020) } \\
- & \text { Audiovisual sector support } \\
- & \text { Support in culture and creative } \\
& \text { industries } \\
- & \text { Support in culture and media }\end{array}$ & 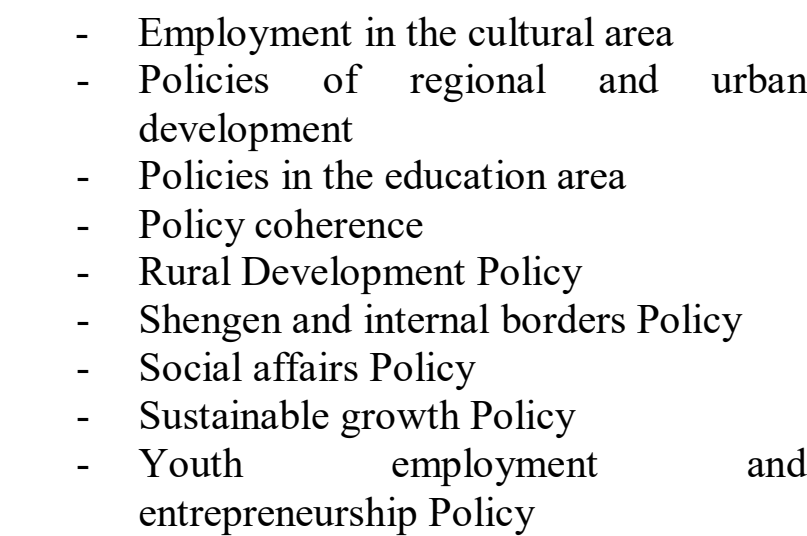 \\
\hline
\end{tabular}

Source: Author's table after Bianchini [14], Sarikakis [22], Shore [21] and Banus [13]

Analyzing the above table, we get to the conclusion that the EU supported the culture as a source of empowering the economy until it created a link between them. In 2006 Chris Shore wrote "to access the cultural domain, the EU should focus on the interests of the member states in this area, and then link the culture to these fields of interest of the member states, and lately to include the culture in the treaties" [21].

Given the fact that culture and economy are linked, in the next part of the paper we will focus on analyzing the factors that influence the economy to see if they affect culture too.

\section{Factors of Influence}

We find that the most significant influence on the economy has the economic and financial crises. We decided to focus on Europe economic crises between 1973 and 2018. These crises not only have influenced the EU economy, but also its structure and the evolution of its policies. During this time we found seven crises with impact on the economy (See the below scheme).

Scheme 1: Crisis moments in the EU

\begin{tabular}{lllllll}
\hline $1973-1987$ & 1990 & 2000 & 2008 & 2014 & 2015 & 2016
\end{tabular}

Source: Author's axis

In 1973 we had the oil crisis which continues with an economic crisis. In this period, we have the European states that abandon the European project and focus on their national affairs. Sauron calls Europe in this time "the Europe of yards" [23].

This crisis is followed by the 1990 economic crisis which affected the structures of both: EU and the national states [12]. After ten years Europe is hit by another economic crisis which caused "changes and a turning point in the welfare states, representative democracy, working relations" [24].

Even Europe has had many economic crises, it did not learn how to face them. This has been a reason why in 2008 it was hit by the most significant economic crisis the World have seen. The European Commission underlines in a 2009 report that the effects of the crisis have had a cultural and social impact, characterized by redundancies in theatres, cinemas and art people [25]. 
The following crises that have hit Europe, were of a different nature: in 2014 EU got affected by Ukraine crisis (security crisis), 2015 - immigrant crisis (social crisis), 2016 - Brexit (political crisis). These crises did not affected EU and its economy so much how did the 2008-2009 economic crisis. This is why we will focus on the impact of this crisis on the EU economy and to the domains related to it, like culture.

\section{The Economic Crisis Effects on Culture}

The economic crises have been a 'nightmare' to the European Union. Starting from the idea that the EU has been founded as an organization with an economic and commercial nature, we observe that the economic crises have the most significant impact on the Union. Because the Organization evolved from an economic structure to an economic, political, socio-cultural structure, we suppose that the economic crises will have an impact not only on the economic field.

We already observed that between economy and culture has been created a link for two reasons: to empower culture as a sustaining pillar of the economy and for EU to have the possibility of accessing the culture of the EU member states, to collaborate better in this field.

Starting from these ideas, we suppose that the economic crises should have an impact on the cultural field too.

In 2011, Ioan-Franc Moldoveanu published a work on the 2008 economic crisis. The author enumerates a few chain reactions in the Netherlands and Romania. In the Netherlands, the Government decides to cut culture funds by 200 million euros. This decision lead to "closing theatres, orchestras, companies of dance, dismissal of culture managers and so on." In Romania, the author notes changes like closing down the cultural clubs in Vâlcea region. As a result, in 2013 the area still has no cultural clubs [26].

The economic crisis impact on the cultural field has been felt in many corners of Europe (see the below table).

Table 2: The economic crisis effects on states cultures

\begin{tabular}{|c|c|c|}
\hline Country & Crisis results in the cultural field & Solutions to overcome the cultural crisis \\
\hline Belgium & $\begin{array}{l}4.4 \text { million euros from the culture } \\
\text { budget were frozen }\end{array}$ & $\begin{array}{l}\text { The cultural organizations support the } \\
\text { campaigns organized as a response to the } \\
\text { cuts. }\end{array}$ \\
\hline Croatia & $\begin{array}{l}\text { The budget for culture felt from } 20 \\
\text { million euros to } 8 \text { million }\end{array}$ & $\begin{array}{l}\text { The government support cultural } \\
\text { organizations to face the undermining } \\
\text { dynamism of the arts and the participation } \\
\text { of the public in culture. }\end{array}$ \\
\hline Estonia & $\begin{array}{l}\text { The cultural institutions had fund } \\
\text { reductions by } 15 \% \text { in } 2008 \text {, and in } \\
2010 \text { further, a decrease of } 9 \% \text {. The } \\
\text { theatres received by } 12 \% \text { fewer } \\
\text { funds in } 2009 \text {. }\end{array}$ & $\begin{array}{l}\text { The theatres prepare campaigns to avoid } \\
\text { further fund reductions. }\end{array}$ \\
\hline Germany & $\begin{array}{l}\text { Germany does cuts in the cultural } \\
\text { sector too. Temporary is closed the } \\
\text { Hamburg Kunsthalle. } \\
\text { The budget cuts for culture are made } \\
\text { in each region between } 14 \text { and } 15 \% \text {. }\end{array}$ & $\begin{array}{l}\text { The government sustains the art and culture } \\
\text { even the area is not able to avoid the } \\
\text { financial cuts. }\end{array}$ \\
\hline Latvia & $\begin{array}{l}\text { Funds for professional arts has been } \\
\text { cut by } 48 \% \text {, for the National Opera } \\
\text { by } 55 \% \text {, film area by } 67 \% \text {, art and } \\
\text { literature } 40 \% \text {. }\end{array}$ & $\begin{array}{l}\text { The cultural organizations start the } \\
\text { campaign "I support culture." The } \\
\text { government has raised the question of } \\
\text { cultural strategies in the cultural sector. }\end{array}$ \\
\hline
\end{tabular}




\begin{tabular}{|c|c|c|}
\hline Lithuania & $\begin{array}{l}\text { Budget cuts by } 20 \% \text { in culture, from } \\
\text { which } 200 \text { million euros cuts for the } \\
\text { arts. }\end{array}$ & $\begin{array}{l}\text { The government support the young artists } \\
\text { and focus on investment funds. }\end{array}$ \\
\hline Norway & $\begin{array}{l}\text { The cuts are not significant, but the } \\
\text { cultural organizations face big } \\
\text { problems to secure the sponsors } \\
\text { from the business community. }\end{array}$ & $\begin{array}{l}\text { The government focuses on increasing the } \\
\text { budget for culture. }\end{array}$ \\
\hline Portugal & $\begin{array}{l}\text { The government tries to avoid cuts } \\
\text { by reducing the budgets for other } \\
\text { areas. }\end{array}$ & $\begin{array}{l}\text { The Ministry of culture tries to avoid the } \\
\text { cuts in the culture and made cuts in } \\
\text { international representation. In the North of } \\
\text { Portugal is released the idea of private } \\
\text { investments. }\end{array}$ \\
\hline Slovenia & $\begin{array}{l}\text { The crisis effects are felt even after } \\
\text { the crisis. In } 2011 \text { the government } \\
\text { reduced the budget for culture by } \\
5 \% \text {. }\end{array}$ & $\begin{array}{l}\text { The Ministry of Culture still tries to } \\
\text { encourage the arts. }\end{array}$ \\
\hline Spain & $\begin{array}{l}\text { The cuts are made in all culture } \\
\text { branches. The effects were } \\
\text { significant in the audiovisual sector. }\end{array}$ & $\begin{array}{l}\text { The government avoid the significant cuts } \\
\text { and try to encourage the culture. }\end{array}$ \\
\hline Sweden & $\begin{array}{l}\text { The cultural budgets were } \\
\text { diminished at the regional level. }\end{array}$ & $\begin{array}{l}\text { The political sphere sustains the recovering } \\
\text { of the creative industries, the prevalent } \\
\text { traditional arts before the crisis. }\end{array}$ \\
\hline $\begin{array}{l}\text { United } \\
\text { Kingdom }\end{array}$ & $\begin{array}{l}\text { The significant cuts were done for } \\
\text { culture and sports }(25-30 \%) \text {. }\end{array}$ & $\begin{array}{l}\text { The society sustains the funding of culture } \\
\text { by the market. Local government tries to } \\
\text { recover the funding process even under the } \\
\text { pressure of the central government that } \\
\text { perceives taxation and cuts. }\end{array}$ \\
\hline
\end{tabular}

Source: Author's table after 2010 prospect for art and culture in Europe by SICA

Similar to the SICA prospect, in 2013 ENCATC initiated a policy debate on this subject. Multiple authors discussed the spillover effect that the economic crisis had had one the cultural field.

One of the authors is Annick Shramme. By analyzing the EU between 2011 and 2013 the author observes that many of the EU member states have reduced their budget for culture by $20-30 \%$. The cuts are found in many changes: "stable jobs changed in short-time contracts, many authors publish their works on the black market to survive, the state requires the help of volunteers instead of professionals [27]. Different from Shramme, Julek Jurowicz focuses on finding solutions to the problems created to the cultural field by the economic crisis. He proposes to focus on helping the artists to overcome the crisis and finding new fund sources [28]. Related to Jurowicz solutions, Pierre Bayens suggests finding new methods of governance, connected to the social values and consumer behavior, to view the economic and cultural policies through an external angle [29].

Amselem proposes an entirely different solution. He says that we should combine the financial resources with the intellectual ones, to encourage the formation of internalization strategies for museums and other cultural representatives, to reduce the museum dependence on public and private subsidies [30]. Seroen proposes a solution based on the same principle of reducing the culture dependence on public subsidies. He sees that we can minimize culture dependence on the economy by applying the idea of the financial contribution of many people to achieve an economic boundary and a cultural project [31]. 
The European institutions were focused on overcoming the effects of the economic crises too. In 2009 the European Commission presented a few strategies concentrated on testing and restructuring the banks. To implement these strategies, the EU proposed a unique system based on

a) ESFS (a European System of Financial Supervision) that was focused on strong coordination, cooperation, and partnership for defining the technical supervisory standards;

b) ESRC (a European Systemic Risk Council), responsible for macro-prudential oversight of the financial system [25, pp. 78-86].

At first look, we can say that the economic crisis has a significant influence on the cultural field. We suppose that the spillover effect is felt in other domains related to the economy, like culture.

The spillover effect is an automatic process triggered by a change in one area- economy spread the positive or the negative change to the domains linked to the first affected field. This explains why in the time of the economic crisis when the economy falls- culture falls too.

This way, we see that our expectations from the beginning of the paper were confirmed.

\section{Conclusions}

The economic crisis has always been a problem to both: national states and the EU. An economic crisis is not seen as a problem from the evolutionist point of view, because it represents the trigger of change in the economy, that at the end brought us the economic system that we have today.

Even an economic crisis can be a positive factor of change; it brings problems in many areas that we would like to avoid. One of these areas is culture. We have tried to track the impact of the 2008-2009 economic crisis on the cultural field. We found that the crisis brings culture budget cuts to zero in some regions, job cuts and finally reduces the role of culture in the society. This impact of the economic crisis on culture is due to the spillover effect. It can make changes in the cultural field after the economy has been affected because of the link created between economics and culture.

We find that the existing link is not the biggest problem, but the fact that culture entirely depends on the economy. If the economy grows - the cultural field gets more funds and therefore can flourish. However, on the other side, if the economy gets hit by an economic crisis, the spillover effect splits the impact on the cultural field too.

Giving the above observations, it can look that it is not possible to separate culture from the economy because the last one assures the development of the first. Still, Seroen solution, crowdfunding seems to be a perfect one. So we focus on finding more solutions to overcome the impact of the economic crisis on culture.

One of the few solutions that we propose after analyzing Seroen, Amselem, Bayens, Juorwicz, Shrame, Moldoveanu is: to reduce the dependence of culture on the subsidies of the national states; to broad the cultural collaboration opportunities; to prepare a group of experts at the supranational level that will have the mission to prepare the EU for an unstoppable crisis, to propose solutions for the member states of the EU and to build long-term strategies to overcome the crises; to create an international, intercultural network for experience exchange and support in time of crises; to develop at the EU level a direction specialized in solving crises. These solutions may be useful to the EU in overcoming the crises that it faces and those to come.

\section{References}

[1] R. Heilbroner, L. Thurow, Economics Explained. Everything you need to know about how the economy works and where it's going. New York: Touchstone, 1982.

[2] N.G. Mankiw, Principles of Economics, 2nd ed., Forth Worth: Harcourt Publishers, 2001.

[3] P. Krugman, R. Wells, Microeconomics, New York: Worth, 2004.

[4] D.C. Colander, Economics, 6th ed., Boston: McGraw-Hill Irwin, 2006.

[5] M. Backhouse, Retrospectives on the definition of economics, Journal of Economics Perspectives. 23(1) (2009) 221-233. 
[6] Financial Dictionary. (2018, 04 03). Economic policy. Retrieved 04 03, 2018, from Financial dictionary. Available: https://financial-dictionary.thefreedictionary.com/economic+policy

[7] D. Throsby, The Economics of Cultural Policy. Cambridge, New York, Melbourne: Cambridge University Press, 2010.

[8] F. Murgas, H. Bohm, Does Economic growth improve quality of life? 15th International Multidisciplinary Scientific GeoConference SGEM, 2014, pp. 1-8.

[9] T. Persson, G. Tabellini, Political economics. Explaining economic policy. Massachusetts: MIT Press, 2000.

[10] D. Baker, G. Epstein, R. Pollin, Globalization and Progressive Economic Policy. Cambridge, Massachusetts: Cambridge University Press, 1998.

[11] K.E. Poole et al., (2018, 04 03). Government economic policy. Retrieved 04 03, 2018, from Encyclopedia Britannica. Available: https://www.britannica.com/topic/government-economicpolicy/Introduction

[12] L. Jonung, T. Hagberg, How costly was the crisis of the 1990s? A comparative analysis of the deepest crises in Finland and Sweden over the last 130 years (No. 224). Directorate General Economic and Financial Affairs (DG ECFIN), European Commission, 2005.

[13] E. Banus, Cultural Policy in the EU and the European Identity. In M. Farell, Fella, Newman, Banus, European integration in the twenty century: unity in diversity?, SAGE, 2002.

[14] F. Bianchini, Remarking European cities: the role of cultural policies. In B. Franco, Cultural Policy \& Urban Regeneration: the West European Experience (p. 220). Manchester: Manchester University Press, 1993.

[15] T. Dumont, Cultural diversity and subsidiarity: The case of cultural tourism in the European Union. European Studies.24 (2007) 45-64.

[16] L. McGowan, Theorizing European Integration: revisiting neo-functionalism and testing suitability for explaining the development of EC competition policy? European Integration online Studies, 2007, pp. 1-19.

[17] I. Bărbulescu, Noua Europă. Identitate și model european. Iași: POLIROM, 2015.

[18] M. Eilsrup-Sangiovani, (2018, 01 23). Debates on European Integration. Retrieved 01 23, 2018, from European Studies. Available: http://hum.port.ac.uk/europeanstudieshub/wp-content/uplo.

[19] D. Kleinshmidt, (2013, 06 11). Neofunctionalism vs. Intergovernmentalism. A comparison of regional integration theories and their connectedness with the European Parliament. Retrieved 01 24, 2018, from Union Files Wordpress. Available: https://ibpunion.files.wordpress.com/2011/09/eu.pdf.

[20] M. Bodziany, Social and cultural factors of the economic crisis in Grece. INTERCATHEDRA. 31(4) (2015) 7-16.

[21] C. Shore, In uno plures? EU Cultural Policy and the Governance of Europe, Cultural Analysis. 5 (2006) 7- 26.

[22] K. Sarikakis, Media and Cultural Policy in the European Union. European Studies. 24 (2007) 45-52.

[23] J.-L. Sauron, Curs de Institutii Europene. Puzzle-ul European. Iași: POLIROM, 2010.

[24] A. Zamora-Kapoor, X. Coller (2015, 05 19). The effects of the crisis: why southern Europe? PMC (US Naţional Library of Medicine, Naţional Institute of Health).

[25] European Commission. (2009). Economic Crisis in Europe: Causes, Consequences and Responses. Economic and Financial Affairs, 1-108. 
[26] M. Moldoveanu, V. Ioan-Franc, The impact of the economic crisis on culture, Review of General Management. (2011) 15-35.

[27] A. Schramme, Culture in challenging times: towards new models of business and governance for the cultural sector. Bruxelles: ENCATC, 2013.

[28] J. Jurowicz, New business models for artists in challenging times. Bruxelles: ENCATC, 2013.

[29] J.-P. Baeyens, New governance models for cultural organizations in challenging times. Bruxelles: ENCATC, 2013.

[30] R. Amsellem, New business models for museums in challenging times. Bruxelles: ENCATC, 2013.

[31] J.-D. Seroen, Redesigning the business model of cultural organizations in a time of economic crisis. Bruxelles: ENCATC, 2013. 